\title{
PENGARUH RELAKSASI OTOT PROGRESIF TERHADAP PENURUNAN TEKANAN DARAH PADA PENDERITA HIPERTENSI DI WILAYAH KERJA PUSKESMAS CURUG KABUPATEN TANGERANG
}

\author{
*Ratumas Ratih Puspita, **Hana Rupaidah \\ Program Studi S1 Keperawatan, STIKes Widya Dharma Husada Tangerang \\ Jalan Pajajaran No1, Pamulang Tangerang Selatan Banten \\ ratumasratihpuspita@wdh.ac.id
}

\begin{abstract}
ABSTRAK
Hipertensi merupakan penyakit penyebab utama stroke,kejadian hipertensi yang meningkat setiap tahun mengindikasikan bawa hipertensi perlu dan harus segera diatasi. Di Puskesmas Curug Kabupaten Tangerang memiliki tingkat insiden kejadian hipertensi essensial (primer) yang menduduki peringkat tertinggi dalam laporan bulanan penyakit menonjol pada bulan Januari- Maret tahun 2018. Disebabkan oleh pola makan yang tidak sehat, selain itu beban kerja yang tinggi. Selama ini masayarakat di wilayah Curug Kulon apabila timbul gejala keluhan tindakan yang dilakukan adalah memeriksa kesarana fasilitas kesehatan memilih pengobatan farmakologi tanpa memikirkan efek samping, kurangnya pengetahuannya tentang metode non farmakologi dalam menurunkan tekanan darah pada hipertensi. Tujuan penelitian ini adalah untuk mengatahui apakah ada pengaruh relaksasi otot progresif terhadap penurunan tekanan darah pada penderita hipertensi diwilayah kerja Puskesmas Curug Kabupaten. Penelitian ini menggunakan metode Pre Eksperimental Design. Dengan rancangan One Group pratest-posttest Design. menggunakan Non Probability dengan dengan teknik purposive sampling. Besar sampel yang akan diteliti sebanyak 12 responden yang diambil dari pasien hipertensi yang tidak melakukan kunjungan ulang sampai dengan bulan april 2018 dengan ketentuan yang memenuhi syarat inklusi dalam penelitian ini. Alat ukur yang digunakan yaitu spygmomanometer air raksa yang sudah dikalibrasi dan stetoskop untuk mengukur tekanan darah di arteri dan lembar observasi. Uji statistik yang digunakan yaitu Wilcoxon Sign Rank Test. Hasil penelitian yang diperoleh yaitu terdapat perbedaan signifikan tekanan darah sebelum dan sesudah diberikan relaksasi otot progresif intervensi selama 7 kali dalam 1 minggu. Kesimpulan dari penelitian ini yaitu bahwa relaksasi sangat penting bagi penderita hipertensi kerena hal tesebut dapat mempengaruhi untuk menurunkan tekanan darah.
\end{abstract}

Kata Kunci : Relaksasi Otot Progresif, Hipertensi

\begin{abstract}
Hypertension is a major cause of stroke. An increased incidence of hypertension each year is indicated that hypertension should be handled promptly. At Puskesmas Curug, Tangerang District, an incidence rate of essential hypertension (primary) was ranked highest in monthly report on January-March 2018. It was caused by unhealthy diet, moreover to heavy workload. Recently, when the symptoms of hypertension arose, society in Curug Kulon check their health in the health facility with pharmacological treatment without thinking about it side effects because their deficient knowledge about non-pharmacological methods in lowering blood pressure for hypertension. The purpose of this research is to determine whether there is a progressive muscle relaxation effect on the decreasing of blood pressure for hypertensive patients in the working area of Puskesmas Curug District. This research used Pre Experimental Design method with One Group pratestposttest Design and Non-Probability with purposive sampling technique. The sample obtained in this research is 12 respondents taken from hypertension patients who did not recheck their health until April 2018 with the inclusion requirements in this study. The tool used in this research is calibrated mercury spygmomanometer, stethoscope to measure blood pressure in artery, and observation sheet. The statistical test used Wilcoxon Sign Rank Test. The result of this research shows that there is significant differences of blood pressure before and after giving progressive muscle relaxation intervention for 7 times in 1 week. The conclusion of this research is relaxation is very important for people with hypertension because it can affect to lower blood pressure.
\end{abstract}

Keywords : Progressive Muscle Relaxation, Hypertension 
PENDAHULUAN

Berdasarkan

data World Health

Organization (WHO) 2015, satu diantara lima orang dewasa di seluruh dunia mengalami peningkatan tekanan darah. Prevalensi kejadian hipertensi diseluruh dunia sekitar 972 juta orang atau 26,4\% masyarakat dunia mengalami hipertensi. Angka ini kemungkinan akan mengalami peningkatan menjadi $29,2 \%$ di tahun 2030 .

Dari 972 juta penderita hipertensi, 333 juta berada di negara maju dan sisanya (639 juta) berada di negara berkembang. Prevalensi hipertensi tertinggi berada di daerah Afrika yaitu $46 \%$ orang dewasa berusia di atas 25 tahun setelah didiagnosis hipertensi (WHO, 2013).

Berdasarkan data Riskesdas 2013 prevalensi hipertensi di Indonesia berdasarkan hasil pengukuran pada umur $\leq 18$ tahun sebesar $25,8 \%$. Jadi cakupan nakes hanya $36,8 \%$, sebagian besar $63,2 \%$ kasus hipertensi dimasyarakat tidak terdiagnosis. Prevalensi hipertensi pada umur $\leq 18$ tahun menurut Provinsi Banten berdasarkan diagnosa pengukuran salah satunya yaitu Kabupaten Tangerang (23,6\%). Dari data prevalensi hipertensi pada umur $\leq 18$ tahun menurut Provinsi Banten yaitu Kabupaten Tangerang dengan hasil $(23,6 \%)$. Berdasarkan data Riskesdas Provinsi Banten 2013 hasil dari Badan Penelitian di Kabupaten Tangerang pengukuran dari data parameter pengetahuan, sikap dan perilaku dikumpulkan pada penduduk kelompok umur 10 tahun atau lebih yaitu menurut mengkomsumsi makanan asin $\geq 1$ kali perhari $(28,0 \%)$, kebiasaan merokok setiap hari (25,0\%), aktivitas aktif (78,5\%), aktivitas kurang aktif (21,5\%), mengkomsumsi makanan berlemak $(58,2 \%)$, mengkomsumsi makanan bumbu penyedap $\geq 1$ kali perhari (80,0\%), mengkomsumsi minuman kopi $\geq 1$ kali perhari (3,0\%), mengkomsumsi makanan hewani berbahan pengawet $\geq 1$ kali perhari $(3,3 \%)$, komsusmsi makanan mie instan $\geq 1$ kali perhari $(12,7 \%)$, mengkomsumsi makanan dibakar/panggang $\geq 1$ kali perhari (2,7\%), mengkomsumsi minuman berkafein buatan $\geq 1$ kali perhari $(3,0 \%)$. Dari data tersebut peningkatan jumlah penderita hipetensi di Kabupaten Tangerang disebabkan oleh pola makan tidak sehat. Penyebab hipertensi antara lain genetik, stres, obesitas, konsumsi garam yang tinggi, merokok, minuman alkohol, adanya penyakit lain (Ridwan, 2009).

Kejadian hipertensi yang meningkat setiap tahun mengindikasikan bahwa hipertensi perlu dan harus segera diatasi. Pengobatan hipertensi terdiri dari terapi farmakologis dan non farmakologis.

Teknik relaksasi otot progresif yaitu memusatkan perhatian pada suatu aktivitas 
otot, dengan mengidentifikasikan otot yang tegang kemudian menurunkan ketegangan dengan melakukan teknik relaksasi untuk mendapatkan perasaan relaks (Purwanto, 2013).

Hasil studi pendahuluan yang sudah dilakukan pada masyarakat di wilayah Kerja Puskesmas Curug Kabupaten Tangerang juga didapatkan bahwa mayoritas masyarakat di wilayah Desa Curug Kulon memiliki tingkat insiden kejadian hipertensi essensial (primer) yang menduduki peringkat tertinggi sebanyak 864 atau 8,64\% yang disebabkan oleh seringnya mengkomsumsi tinggi garam, makanan yang berlemak, serta merokok, selain itu beban kerja yang tinggi dan tidak mengetahui kemudahan dalam pelaksanaan tentang tindakan keperawatan metode non farmakologi yaitu relaksasi otot progresif untuk menurunkan tekanan darah. Selama ini masyarakat diwilayah kerja Puskesmas Curug tindakan yang dilakukan pada tekanan darah tinggi adalah memeriksakan ke sarana fasilitas kesehatan apabila timbul gejala keluhan.

Dari permasalahan tersebut peneliti tertarik untuk melakukan penelitian tentang” Pengaruh Relaksasi Otot Progresif Terhadap Penurunan Tekanan Darah pada Penderita Hipertensi di Wilayah Kerja Puskesmas Curug Kabupaten Tangerang”.

\section{Metode}

Rancangan penelitian ini menggunakan metode Pre Eksperimental Design. Dengan rancangan One Group pratest-posttest Design yaitu eksperimen yang dilaksanakan pada satu kelompok saja tanpa perbandingan (Nursalam, 2014).

Populasi dalam penelitian adalah pasien yang memiliki tekanan darah tinggi yaitu dari bulan januari sampai dengan maret tahun 2018 yaitu 23 orang di Desa Curug kulon Kabupaten Tangerang. Tetapi dalam penelitian ini yang menjadi subjek penelitian adalah pasien hipertensi yang tidak melakukan kunjungan ulang sampai dengan bulan april 2018. Teknik pengambilan sampel menggunakan Non Probability berupa teknik purposive sampling

Besar sampel yang akan diteliti sebanyak 12 orang dengan ketentuan yang memenuhi syarat inklusi dalam penelitian ini. Maka responden dalam penelitian ini sebanyak 12 orang.

Instrumen yang digunakan dalam penelitian ini adalah alat spygmomanometer air raksa yang sudah dikalibrasi dan stetoskop untuk mengukur tekanan darah di arteri, lembar observasi. Hasil pengukuran dengan spygmomanometer air raksa ini kemudian dicacat dilembar observasi untuk ditabulasi 
Cara pengumpulan data dilakukan dengan terlebih dahulu melakukan pendekatan dengan responden, menjelaskan tentang penelitian dan ketersediaan menjadi responden. Responden yang setuju berpartisipasi dalam penelitian diminta untuk menandatangani lembar kesediaan menjadi responden.

\section{Hasil}

Tabel 1 Distribusi Frekuensi tekanan darah sistol sebelum dan sesudah intervensi

\begin{tabular}{|c|c|c|c|c|c|c|}
\hline No & Tekanan darah & $\mathrm{N}$ & Mean & SD & Min & $\operatorname{Max}$ \\
\hline 1 & $\begin{array}{l}\text { Diastol sebelum } \\
\text { intervensi hari1 } \\
\text { Diastol sesudah } \\
\text { intervensi hari1 }\end{array}$ & 12 & $\begin{array}{l}100,8 \\
3 \\
90,83\end{array}$ & $\begin{array}{l}10,836 \\
10,836\end{array}$ & $\begin{array}{l}90 \\
80\end{array}$ & $\begin{array}{l}120 \\
110\end{array}$ \\
\hline 2 & $\begin{array}{l}\text { Diastol sebelum } \\
\text { intervensi hari } 2 \\
\text { Diastol sesudah } \\
\text { intervensi hari } 2\end{array}$ & 12 & $\begin{array}{l}95,83 \\
88,33\end{array}$ & $\begin{array}{l}9,003 \\
11,934\end{array}$ & $\begin{array}{l}80 \\
80\end{array}$ & $\begin{array}{l}110 \\
120\end{array}$ \\
\hline 3 & $\begin{array}{l}\text { Diastol sebelum } \\
\text { intervensi hari } 3 \\
\text { Diastol sesudah } \\
\text { intervensi hari } 3\end{array}$ & 12 & $\begin{array}{l}91,67 \\
83,33\end{array}$ & $\begin{array}{l}9,374 \\
7,785\end{array}$ & $\begin{array}{l}80 \\
80\end{array}$ & $\begin{array}{l}110 \\
100\end{array}$ \\
\hline 4 & $\begin{array}{l}\text { Diastol sebelum } \\
\text { intervensi hari } 4 \\
\text { Diatol sesudah } \\
\text { intervensi hari } 4\end{array}$ & 12 & $\begin{array}{l}90,83 \\
84,17\end{array}$ & $\begin{array}{l}7,930 \\
6,686\end{array}$ & $\begin{array}{l}80 \\
80\end{array}$ & $\begin{array}{l}100 \\
100\end{array}$ \\
\hline 5 & $\begin{array}{l}\text { Diastol sebelum } \\
\text { intervensi hari } 5 \\
\text { Diastol sesudah } \\
\text { intervensi hari } 5\end{array}$ & 12 & $\begin{array}{l}90,83 \\
83,33\end{array}$ & $\begin{array}{l}9,962 \\
6,513\end{array}$ & $\begin{array}{l}80 \\
80\end{array}$ & $\begin{array}{l}110 \\
100\end{array}$ \\
\hline 6 & $\begin{array}{l}\text { Diastol sebelum } \\
\text { intervensi hari } 6 \\
\text { Diastol sesudah } \\
\text { intervensi hari } 6\end{array}$ & 12 & $\begin{array}{l}88,33 \\
82,50\end{array}$ & $\begin{array}{l}7,177 \\
4,523\end{array}$ & $\begin{array}{l}80 \\
80\end{array}$ & $\begin{array}{l}100 \\
90\end{array}$ \\
\hline 7 & $\begin{array}{l}\text { Diastol sebelum } \\
\text { intervensi hari } 7 \\
\text { Diastol sesudah } \\
\text { intervensi hari } 7\end{array}$ & 12 & $\begin{array}{l}86,67 \\
80,00\end{array}$ & $\begin{array}{l}4,924 \\
, 000\end{array}$ & $\begin{array}{l}80 \\
80\end{array}$ & $\begin{array}{l}90 \\
80\end{array}$ \\
\hline
\end{tabular}

Tabel 2 Distribusi Frekuensi tekanan darah diastol sebelum dan sesudah intervensi

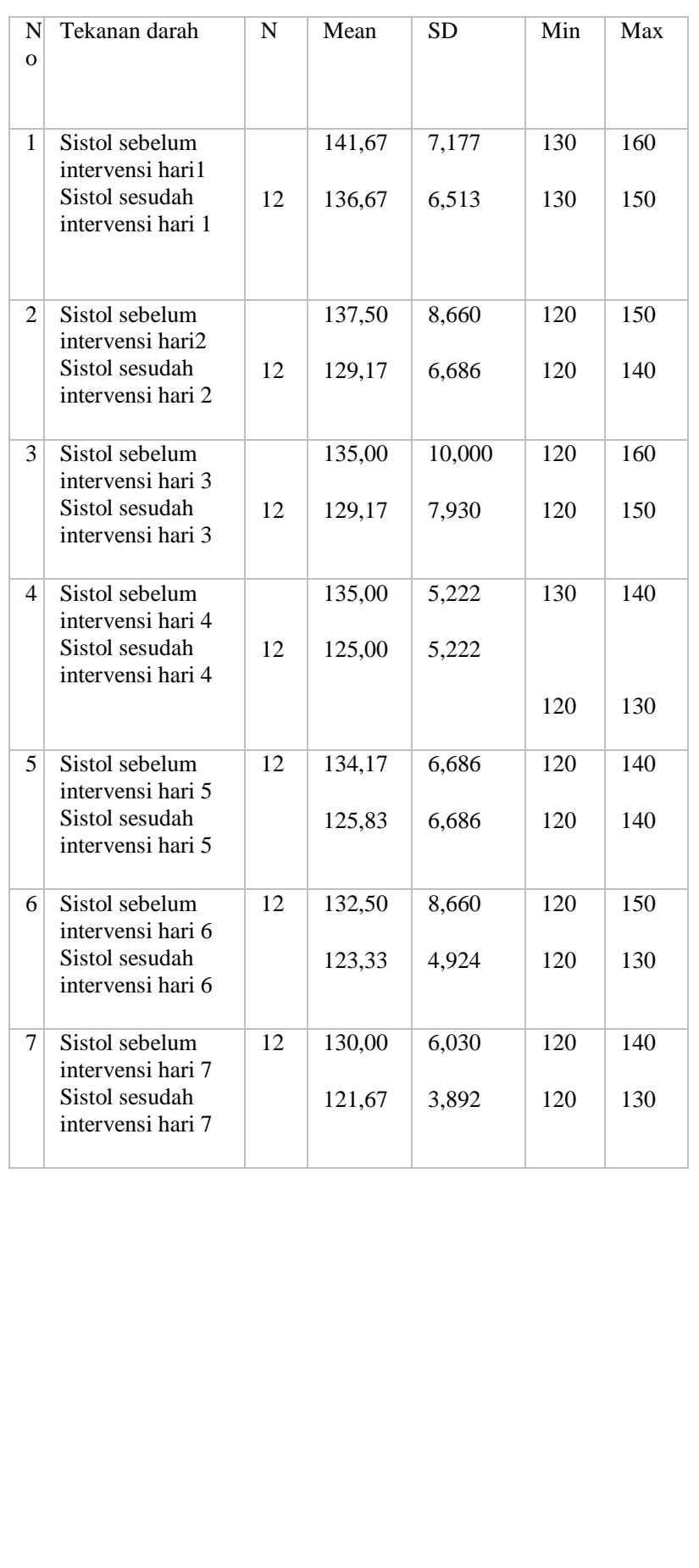


Tabel 3 Pengaruh relaksasi otot progresif terhadap penurunan tekanan darah sistol pada penderita hipertensi diwilayah kerja Puskesmas Kabupaten Tangerang

\begin{tabular}{|c|c|c|c|c|}
\hline Tekanan Darah & $\mathrm{N}$ & Mean & $\mathrm{Z}$ & $p$-value \\
\hline $\begin{array}{l}\text { Tekanan darah sistol } \\
\text { sebelum intervensi1 } \\
\text { Tekanan darah sistol } \\
\text { sesudah intervensi1 }\end{array}$ & 12 & $\begin{array}{l}141,67 \\
136,67\end{array}$ & $\begin{array}{l}- \\
2,4 \\
49\end{array}$ & ,014 \\
\hline $\begin{array}{l}\text { Tekanan darah sistol } \\
\text { sebelum intervensi2 } \\
\text { Tekanan darah sistol } \\
\text { sesudah intervensi2 }\end{array}$ & 12 & $\begin{array}{l}137,50 \\
129,17\end{array}$ & $\begin{array}{l}- \\
3,1 \\
62\end{array}$ & ,002 \\
\hline $\begin{array}{l}\text { Tekanan darah sistol } \\
\text { sebelum intervensi3 } \\
\text { Tekanan darah sistol } \\
\text { sesudah intervensi3 }\end{array}$ & 12 & $\begin{array}{l}135,00 \\
129,17\end{array}$ & $\begin{array}{l}- \\
2,6 \\
46\end{array}$ & ,008 \\
\hline $\begin{array}{l}\text { Tekanan darah sistol } \\
\text { sebelum intervensi4 } \\
\text { Tekanan darah sistol } \\
\text { sesudah intervensi14 }\end{array}$ & 12 & $\begin{array}{l}135,00 \\
125,00\end{array}$ & $\begin{array}{l}- \\
3,4 \\
64\end{array}$ & ,001 \\
\hline $\begin{array}{l}\text { Tekanan darah sistol } \\
\text { sebelum intervensi5 } \\
\text { Tekanan darah sistol } \\
\text { sesudah intervensi5 }\end{array}$ & 12 & $\begin{array}{l}134,17 \\
125,83\end{array}$ & $\begin{array}{l}- \\
3,1 \\
62\end{array}$ & ,002 \\
\hline $\begin{array}{l}\text { Tekanan darah sistol } \\
\text { sebelum intervensi6 } \\
\text { Tekanan darah sistol } \\
\text { sesudah intervensi6 }\end{array}$ & 12 & 123,33 & $\begin{array}{l}- \\
3,0 \\
51\end{array}$ & ,002 \\
\hline $\begin{array}{l}\text { Tekanan darah sistol } \\
\text { sebelum intervensi7 } \\
\text { Tekanan darah sistol } \\
\text { sesudah intervensi7 }\end{array}$ & 12 & $\begin{array}{l}130,00 \\
121,67\end{array}$ & $\begin{array}{l}- \\
3,1 \\
62\end{array}$ & ,002 \\
\hline
\end{tabular}

Tabel 4 pengaruh pemeberian relaksasi otot progresif terhadap penurunan tekanan darah diastolpada penderita hipertensi diwilayah kerja puskesmas curug kabupaten tangerang

\begin{tabular}{|c|c|c|c|c|}
\hline Tekanan Darah & $\mathrm{N}$ & Mean & $\mathrm{Z}$ & $\begin{array}{l}p \text { - } \\
\text { value }\end{array}$ \\
\hline $\begin{array}{l}\text { Tekanan darah diastolik } \\
\text { sebelum intervensi1 } \\
\text { Tekanan darah diastolik } \\
\text { sesudah intervensi1 }\end{array}$ & 12 & $\begin{array}{l}100,83 \\
90,83\end{array}$ & $-2,972$ & ,003 \\
\hline $\begin{array}{l}\text { Tekanan darah diastolik } \\
\text { sebelum intervensi2 } \\
\text { Tekanan darah diastolik } \\
\text { sesudah intervensi12 }\end{array}$ & 12 & $\begin{array}{l}95,67 \\
88,33\end{array}$ & $-2,714$ & ,007 \\
\hline $\begin{array}{l}\text { Tekanan darah diastolik } \\
\text { sebelum intervensi3 } \\
\text { Tekanan darah diastolik } \\
\text { sesudah intervensi3 }\end{array}$ & 12 & $\begin{array}{l}91,67 \\
83,33\end{array}$ & $-3,162$ & ,002 \\
\hline $\begin{array}{l}\text { Tekanan darah diastolik } \\
\text { sebelum intervensi4 } \\
\text { Tekanan darah diastolik } \\
\text { sesudah intervensi4 }\end{array}$ & 12 & $\begin{array}{l}90,83 \\
84,17\end{array}$ & $-2,828$ & 005 \\
\hline $\begin{array}{l}\text { Tekanan darah diastolik } \\
\text { sebelum intervensi5 } \\
\text { Tekanan darah diastolik } \\
\text { sesudah intervensi5 }\end{array}$ & 12 & $\begin{array}{l}90,83 \\
83,33\end{array}$ & $-2,714$ & ,007 \\
\hline $\begin{array}{l}\text { Tekanan darah diastolik } \\
\text { sebelum intervensi6 } \\
\text { Tekanan darah diastolik } \\
\text { sesudah intervensi6 }\end{array}$ & 12 & $\begin{array}{l}88,33 \\
82,50\end{array}$ & $-2,646$ &, 008 \\
\hline $\begin{array}{l}\text { Tekanan darah } \\
\text { diastoliksebelum intervensi7 } \\
\text { Tekanan darah diastolik } \\
\text { sesudah intervensi7 }\end{array}$ & 12 & 86,67 & $-2,828$ & 005 \\
\hline
\end{tabular}

Hasil analisis diperoleh data menunjukkan rata-rata tekanan darah sebelum diberikan relaksasi otot progresif dari intervensi 1-7 menunjukkan bahwa rata-rata tekanan darah sistol sebelum diberikan relaksasi otot progresif yaitu mulai dari 130,00 mmHg sampai 141, $67 \mathrm{mmHg}$ dan tekanan darah diastol sebelum dilakukan relaksasi otot progresif yaitu mulai dari $86,67 \mathrm{mmHg}$ sampai 100,83 mmHg. Berdasarkan hasil 
penelitian menunjukkan bahwa tekanan darah sistol sesudah relaksasi otot progresif dari intervensi 1-7 yaitu mulai dari 121,67 $\mathrm{mmHg}$ sampai 136,67 mmHg dan tekanan darah diastol sesudah dilakukan relaksasi otot progresif yaitu mulai dari $80,00 \mathrm{mmHg}$ sampai $136,67 \mathrm{mmHg}$.

Hasil uji statistik analisis Berdasarkan hasil uji analisis Wilcoxon Sign Rank Test menunjukkan adanya pengaruh relaksasi otot progresif dalam menurunkan tekanan darah pada pasien hipertensi diwilayah Desa Curug Kulon Kabupaten Tangeang. penelitian yang dilakukan selama 7 kali selama 1 minggu

\section{PEMBAHASAN}

\section{Tekanan darah sebelum intervensi}

Hipertensi adalah keadaan seseorang yang mengalami peningkatan tekanan darah diatas normal sehingga mengakibatkan peningkatan angka morbiditas maupun mortalitas, tekanan darah fase sistolik 140 mmHg menunjukkan fase darah yang sedang dipompa oleh jantung dan fase diastolik $90 \mathrm{mmHg}$ menunjukkan fase darah yang kembali ke jantung (Triyanto, 2014).

Peningkatan tekanan darah berhubungan dengan faktor psikologis, emosional, ansientas, depresi dan faktor pdikososial, salah satu bentuk cara meredakan ketegangan otot yang cukup mudah dilakukan adalah relaksasi otot progresif (Shelly, 2009). Manfaat dari relaksasi otot progresif adalah untuk mengatasi berbagai macam permasalahan dalam mengatasi stres, kecemasan, insomia dan juga dapat menurunkan tekanan darah.

Menurut peneliti, berdasarkan hasil penelitian dan teori diatas maka dapat disimpulkan bahwa tekanan darah sebelum dilakukan relaksasi otot progresif tekanan darah yang mengalami peningkatan disebabkan oleh perubahan gaya hidup, kurangnya aktivits fisik dan pola makan yang tidak sehat.

\section{Tekanan darah sesudah intervensi}

Pada penelitian sebelumnya yang dilakukan Valentine (2014) bahwa pengaruh relaksasi otot progresif terhadap lansia hipertensi dengan $\mathrm{p}$ value 0,032 ( sistole) dan $\mathrm{p}$ value 0,008 (diastole) $<0,05$ yang berarti terapi relaksasi otot progresif dapat digunakan sebagai terapi non farmakologi yang tepat dan praktis pada penderita hipertensi. Relaksasi otot progresif adalah suatu rangkaian gerakan ringan serta bergantian menegangkan dan melemaskan 14 bagian otot tubuh sampai terasa lebih rileks.

Teknik relaksasi otot progresif adalah teknik relaksasi otot dalam yang tidak memerlukan imajinasi, ketekunan, atau 
sugesti (Setyoadi \& Kushariyadi, 2011). Relaksasi digunakan untuk mengurangi ketegangan, terutama ketegangan psikis yang berkaitan dengan permasalahan kehidupan.

Menurut peneliti, berdasarkan hasil penelitian dan teori diatas maka dapat disimpulkan bahwa tekanan darah sistol dan diastol sesudah dilakukan relaksasi otot progresif terdapat penurunan tekanan darah

Pengaruh relaksasi otot progresif terhadap penurunan tekanan darah pada penderita hipertensi diwilayah kerja Puskesmas Curug Kabupaten Tangerang

Berdasarkan hasil uji analisis Wilcoxon Sign Rank Test menunjukkan adanya pengaruh relaksasi otot progresif dalam menurunkan tekanan darah pada pasien hipertensi diwilayah Desa Curug Kulon Kabupaten Tangeang. penelitian yang dilakukan selama 7 kali selama 1 minggu. Latihan relaksasi otot progresif yanag mana gerakan-gerakan didalamnya bertujuan untuk menurunkan kecemasan, stres dan menurunkan tingkat depresi. Penurunanan tersebut akan menstimulasi kerja sistem saraf perifer (autonom nervous system) terutama para simpatis yang menyebabkan vasodilatasi pemompoan pembuluh darah akan mengakibatkan terjadinya penurunan tekanan darah baik sistol maupun diastolik ( Pollock, \& Wilmore, 2008).

Rangsangan pada sistem saraf simpatis meningkatkan aktivitas jantung, meningkatkan frekuensi jantung, dan menaikan kekuatan pemompoan. Peningkatan kemampuan jantung dalam memompa darah untuk memenuhi kebutuhan tubuh terhadap oksigen, menyebabkan jantung tidak perlu berdenyut lebih cepat untuk mempoma darah dalam jumlah tertentu seperti sewaktu sebelum berolahraga teratur (Sherwood, 2008).

\section{Kesimpulan}

1. Berdasarkan hasil penelitian Pengukuran tekanan darah sistol dan diastol sebelum dilakukan Relaksasi otot progresif tekanan darah yang mengalami peningkatan disebabkan oleh perubahan gaya hidup, kurangnya aktivits fisik dan pola makan yang tidak sehat.

2. Berdasarkan hasil penelitian menunjukkan bahwa tekanan darah sistol sesudah relaksasi otot progresif dari intervensi 1-7 yaitu mulai dari 121,67 mmHg sampai 136,67 mmHg dan tekanan darah diastol sesudah dilakukan relaksasi otot progresif yaitu mulai dari 80,00 mmHg sampai $136,67 \mathrm{mmHg}$ terdapat 
penurunan tekanan darah. Hal ini penurunana terjadi dikarenakan posisi seseorang sedang dilakukan relaksasi otot progresif terjadi perbedaan tekanan kardiovaskuler antara jantung dengan bagian tubuh saling mempengaruhi.

3. Berdasarkan hasil uji analisis Wilcoxon Sign Rank Test menunjukkan adanya pengaruh relaksasi otot progresif dalam menurunkan tekanan darah pada pasien hipertensi diwilayah Kerja Puskesmas Curug Kabupaten Tangeang. penelitian yang dilakukan selama 7 kali selama 1 minggu.

\section{REFERENSI}

Alim. 2009. "Langkah-Langkah Relaksasi Otot Progresif'.

Herodes, R, .2010. Anxienty and Depression in patient.

Hidayat, A.A. 2014. Metode penelitian keperawatan dan teknis analisis data. Jakarta: Salemba Medika

Muhammadun. 2010. Hidup Bersama Hipertensi. Yogyakarta: In-books.

Muttaqin, Arif. 2009. Asuhan Keperawatan Klien dengan Gangguan Sistem Kardiovaskuler. Jakarta: Salemba Medika.

Notoadmodjo, Soekidjo. (2010). Metodologi Penelitian Keehatan. Jakarta. Rineka.
Notoatmodjo,S. (2012) Metodologi Penelitian Kesehatan.Jakarta : Rineka Cipta.

Potter, P. A., \& Perry, A. G (2010). Fundamentals of nursing 7th edition. (Terj. Dr. Adrina Ferderika Nggie dan dr. Marina Albar). Jakarta: EGC.

Potter dan Perry. 2006. Buku ajar fundamental keperawatan volume 2 . Edisi 4, Jakarta : EGC

Resti, I.B. Teknik Relaksasi Otot Progresif untuk Mengurangi Stres pada Penderita Asma. Jurnal Ilmiah Psikologi Terapan.Volume 2, No.1. Januari 2014

Riset Kesehatan Dasar (Riskesdas) 2013. Pedoman Pewawancara Petugas Pengumpulan Data. Jakarta: Badan Litbangkes, Depkes RI, 2013

Robinson, Joan. M dan Lyndon Saputra. 2014. Buku Ajar Visual Nursing Jilid Satu. Tangerang Selatan: Binarupa Aksara Publisher

Selly. E (2009). Health Psychology. Hal 192-202. Jakarta: Buku Kedokteran.

Sugiyono. 2011. Statistika Untuk Penelitian. Jakarta: Alfabeta.

Susilo, Wulandari. 2011. Cara Jitu Mengatasi Hipertensi. Jakarta: Penerbit Andi

Tanto, Chrish., Liwang, Frans., Hanifan, Sonia., Pradipta, Eka adip.(2014). Kapita Selekta Kedokteran buku 1 edisi 4. Jakarta : Media Aesculapius. 
Valentine, D. A (2014). Pengaruh teknik relaksasi otot progresif terhadap tekanan darah pada lansia dengan hipertensi di kel. Pringapus, kec. Pringapus, kab. Semarang. Diakses 22 Mei (2018) Dari Http://perpusnwu.web.id/Karyailmiah /documents/354.pdf

World Health Organization. A global brief on hypertension: silent killer, global public health crisis. 2015. 